\title{
Selective Inhibition of Potassium Contracture in Guinea Pig Taenia Coli by Ruthenium Red
}

\author{
Masaru Kawamura and Hideyo YabU \\ Department of Physiology, Sapporo Medical College, Sapporo, 060 Japan
}

\begin{abstract}
Effects of ruthenium red on isotonic $\mathrm{KCl}$ induced contracture (K-contracture), cellular ${ }^{45} \mathrm{Ca}$ uptake and ${ }^{45} \mathrm{Ca}$ binding to surface membranes were examined in the smooth muscle cells of guinea pig taenia coli. These results were compared with those using lanthanum $\left(\mathrm{La}^{3+}\right)$.

The tonic component of the K-contracture was selectively inhibited by $1 \mathrm{~mm}$ ruthenium red. In contrast, $1 \mathrm{mM} \mathrm{La}^{3+}$ inhibited the phasic component of the K-contracture to a large extent. Use of $1 \mathrm{~mm}$ ruthenium red selectively inhibited the tonic component of $\mathrm{K}$-contracture and caused a marked decrease in cellular ${ }^{45} \mathrm{Ca}$ uptake in that component of $\mathrm{K}$-contracture. In contrast, $1 \mathrm{mM} \mathrm{La}^{3+}$ largely inhibited the phasic component and caused a significant decrease in cellular ${ }^{45} \mathrm{Ca}$ in that component. According to Scatchard plot analysis, there are two kinds of $\mathrm{Ca}^{2+}$ binding sites of high and low affinity, respectively, on the surface membrane of the taenia coli. One mM ruthenium red suppressed those of low affinity more strongly than those of high affinity. In contrast, $1 \mathrm{mM} \mathrm{La}^{3+}$ suppressed high affinity sites more markedly than low affinity sites.

Based on these results, it seems possible to conclude that ruthenium red mainly blocks the initial binding sites linked with $\mathrm{Ca}^{2+}$ influx which is related to the production of the tonic component while $\mathrm{La}^{3+}$ blocks those sites related to the phasic component of the K-contracture of guinea pig taenia coli.
\end{abstract}

The contraction of smooth muscle is mainly dependent upon extracellular $\mathrm{Ca}^{2+}$ for the activation of contractile protein. This function has been accepted as evidence that $\mathrm{K}$-contracture of guinea pig taenia coli, in its initial rapid phase, is dependent upon the influx of $\mathrm{Ca}^{2+}$ during spike discharge and its subsequent sustained tonic phase is dependent upon $\mathrm{Ca}^{2+}$ influx during $\mathrm{K}$-depolarization (MAYER et al., 1972).

It is generally supposed that a primary and essential step for the influx of $\mathrm{Ca}^{2+}$ is the binding to surface membranes in barnacle muscle (HAGIWARA and TAKAHASHI, 1967), mammalian myocardial tissues (SANBORN and LANGER, 1970) and isolated skeletal sarcoplasmic reticulum (CHEVALLIER and BUTOW,1971).

Received for publication March 13, 1978

川村 勝, 藪 英世 
The terminal group on the saccharide side chain of glycoproteins is always composed of sialic acid and is negatively charged. Calcium binding to the sialic acid residues in the surface of liver mitochondria (Bosmann et al., 1972; SHLATz and MARINETTI, 1972), erythrocytes (LONG and MoUAT, 1971) and liver microsomes (LARSÉN et al., 1972) plays an important role in the regulation of transmembrane $\mathrm{Ca}^{2+}$ flux. Recently, IsHIYAMA et al. (1975) observed that when the taenia coli was treated by neuraminidase (EC 3.2.1.18), K-contracture was suppressed with a decrease in its sialic acid content and they suggested that sialic acid residues were the first sites triggering $\mathrm{Ca}^{2+}$ influx.

In this study we attempted to observe the effects of ruthenium red on cellular $\mathrm{Ca}^{2+}$ uptake and on superficial $\mathrm{Ca}^{2+}$ binding in relation to its effect on $\mathrm{K}$-contracture in guinea pig taenia coli. Ruthenium red is well known as a mucopolysaccharide binding agent (MOORE, 1971; LUFT, 1971). Lanthanum as well has been reported to strongly inhibit $\mathrm{Ca}^{2+}$ binding to $\mathrm{Ca}^{2+}$ binding sites of surface membranes in a competitive manner. Thus, the effects were compared with those of $\mathrm{La}^{3+}$.

Based on the results obtained, the possible existence of two different systems for $\mathrm{Ca}^{2+}$ influx through the surface membranes of smooth muscle cells will be discussed.

Some of these results have already been reported (KAWAMURA et al., 1977).

\section{MATERIALS AND METHODS}

Preparation of sample. Guinea pigs of either sex, weighing 300-500 g, were stunned and bled. The taenia coli was excised and was kept in normal solution for $1 \mathrm{hr}$ before the start of an experiment. The normal solution was a Tris-buffered solution (hereafter called $\mathrm{Na}$-Tris sol.) of the following composition (mM); $\mathrm{NaCl}$, $139.3 ; \mathrm{KCl}, 2.68 ; \mathrm{MgCl}_{2}, 0.5 ; \mathrm{CaCl}_{2}, 1.36$; tris (hydroxymethyl) aminomethane(Tris), 5.0 and glucose, 8.0. It was aerated with $100 \% \mathrm{O}_{2}$ and its $\mathrm{pH}$ was adjusted to 7.4 with $1 \mathrm{~N} \mathrm{HCl}$. Isotonic $\mathrm{KCl}$ solution (K-Tris sol.) was prepared by replacing $\mathrm{NaCl}$ with equivalent amounts of $\mathrm{KCl}$.

Measurement of tension. The taenia coli was mounted in a $5 \mathrm{ml}$ organ bath at $37^{\circ} \mathrm{C}$. One end of strip was tied to a mechano-transducer (Nihon Kohden Ltd., model SB-IT) and the other end to a hook at the bottom of bath. The mechanical responses were recorded on an ink-writing oscillograph (Nihon Kohden Ltd., RJG3022-IS).

Electron microscope study. The procedure for staining with ruthenium red was essentially the same as that described by LuFT (1971). Small pieces (about $1 \mathrm{~mm}^{3}$ ) of taenia coli were prefixed for $1 \mathrm{hr}$ at $4^{\circ} \mathrm{C}$ in a $2.5 \%$ glutaraldehyde solution containing $10^{-3} \mathrm{M}$ ruthenium red and $0.1 \mathrm{M}$ cacodylate buffer $(\mathrm{pH} 7.4)$. The tissue blocks were washed out with a $0.1 \mathrm{M}$ cacodylate buffered solution. Then they were postfixed for $3 \mathrm{hr}$ at room temperature in $1 \%$ osmium tetroxide solution containing 
$10^{-3} \mathrm{M}$ ruthenium red and $0.1 \mathrm{M}$ cacodylate buffer.

${ }^{45} \mathrm{Ca}$ binding and ${ }^{45} \mathrm{Ca}$ uptake. 1) ${ }^{45} \mathrm{Ca}$ binding: Before the start of an experiment, taenia coli was immersed in the $\mathrm{Ca}^{2+}$-free $\mathrm{Na}$-Tris sol. for $5 \mathrm{~min}$ at $20^{\circ} \mathrm{C}$ and then was transferred into a Na-Tris sol. containing ${ }^{45} \mathrm{Ca}(2 \mu \mathrm{Ci} / \mathrm{ml})$. After incubation for $5 \mathrm{~min}$ the reaction was terminated by blotting on filter paper (No. 5, Toyo Roshi Co.) and subsequent washing for $10 \mathrm{sec}$ with the $\mathrm{Ca}^{2+}$-free $\mathrm{Na}$-Tris sol. Blotting was repeated again and the taenia coli was digested with the solubilizer (Soluene-350, Packard Co.). The radioactivity of ${ }^{45} \mathrm{Ca}$ was therafter counted using a liquid scintillation spectrometer (Hitachi-Horiba, LS-700). To determine the binding sites the amounts of $\mathrm{Ca}^{2+}$ binding were measured at two different concentrations of added $\mathrm{Ca}^{2+}\left(1.36 \cdot 10^{-5}\right.$ and $\left.1.36 \cdot 10^{-3} \mathrm{M}\right)$. The ratio of $\mathrm{Ca}^{2+}$ bound to free $\mathrm{Ca}^{2+}$ concentrations can be used to classify these $\mathrm{Ca}^{2+}$ binding sites of different affinities (Rossi et al., 1973). 2) ${ }^{45} \mathrm{Ca}$ uptake: The taenia coli was exposed to a NaTris sol. containing ${ }^{45} \mathrm{Ca}(2 \mu \mathrm{Ci} / \mathrm{ml})$ for a specified period and then washed five times during $1 \mathrm{hr}$ with a nonradioactive $\mathrm{Ca}^{2+} \mathrm{Na}$-Tris sol. containing $20 \mathrm{~mm} \mathrm{La}^{3+}$. Similarly, ${ }^{45} \mathrm{Ca}$ uptake in K-Tris sol. was observed. The subtraction of the amounts of ${ }^{45} \mathrm{Ca}$ uptake in Na-Tris sol. from those in K-Tris sol. led to an estimate of ${ }^{45} \mathrm{Ca}$ uptake during $\mathrm{K}$-contracture.

Agents. Ruthenium red (hereafter called RR), $\mathrm{LaCl}_{3}$ and $\mathrm{RuCl}_{3}$ are commercial products of the best reagent grades available. Radioisotope $\mathrm{Ca}^{2+}$ was purchased from the International Chemical Nuclear Corporation as $\mathrm{CaCl}_{2}$ in $0.5 \mathrm{M}$ $\mathrm{HCl}(6.6 \mathrm{mCi} / \mathrm{mg})$.

\section{RESULTS}

\section{Effects of $\mathrm{RR}$ and $\mathrm{La}^{3+}$ on $\mathrm{K}$-contracture}

As shown in Fig. 1A, K-contracture consisted of two components, an early rapid phasic component and a late sustained tonic one. After pretreatment with $10^{-3} \mathrm{M}$ RR for $10 \mathrm{~min}$ in Na-Tris sol. in the presence of the same concentration of $\mathrm{RR}$ in K-Tris sol. the phasic component of K-contracture was only slightly suppressed but the tonic component was markedly affected, being reduced to about $50 \%$ of the control level. When the bath solution containing RR was replaced with the $\mathrm{Na}$-Tris sol., tension in each component returned to the control level within $10 \mathrm{~min}$. With an increase of $\mathrm{RR}$ up to $5 \cdot 10^{-3} \mathrm{M}$, the inhibition of the tonic component gradually became greater than that of the phasic component (Fig. 1B).

As shown in Fig. 2A, the extent of inhibition was dependent upon the concentration of RR. At a concentration of $\mathrm{RR}, 10^{-4}, 10^{-3}$ and $5 \cdot 10^{-3} \mathrm{M}$, the effect on the phasic component was much less pronounced than on the tonic component. There was approximately $80 \%$ inhibition of the tonic component in K-Tris sol. containing $5 \cdot 10^{-3} \mathrm{M}$ RR but less than $30 \%$ inhibition of the phasic component in the same concentration of RR. A gradual prolongation in the duration of RR $\left(10^{-3} \mathrm{M}\right)$ treatment caused inhibition of both components to be reinforced as shown in Fig. 2B. Throughout the altered treating period tested, the inhibition of the 
A

a b

c

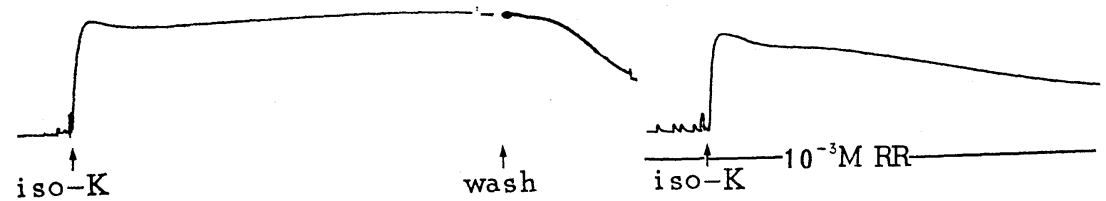

d

e

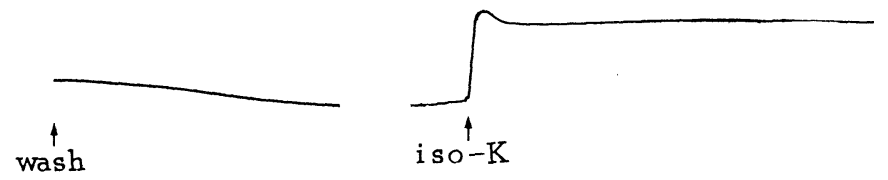

B a

$\mathrm{b}$
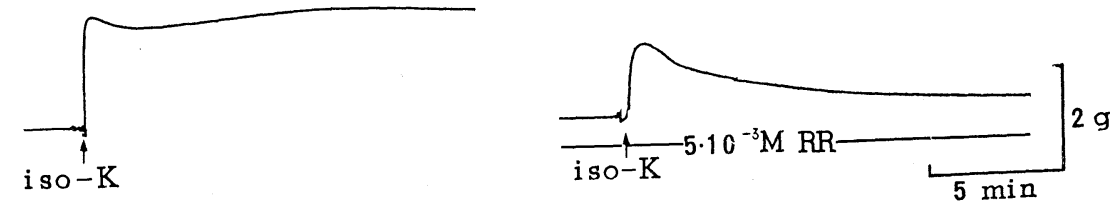

Fig. 1. Effects of RR on K-contracture. Panel A shows the effect of $R R$ at $10^{-3} \mathrm{M}$ and panel $\mathrm{B}$ shows that at $5 \cdot 10^{-3} \mathrm{M}$. In each panel, a shows a control response produced by applying K-Tris sol. In each experiment, the preparation was pretreated with $\mathrm{RR}$ at $10^{-3} \mathrm{M}$ (c in panel $\mathrm{A}$ ) and at $5 \cdot 10^{-3} \mathrm{M}$ (b in panel B), respectively, for $10 \mathrm{~min}$. The preparation was then transferred into a K-Tris sol. containing RR at each concentration. $b$ in panel A shows the recovery from K-contracture by Na-Tris sol. $d$ and e in the same panel show that the inhibitory effect of RR was ceased by washing. iso-K; isotonic $\mathrm{KCl}$ solution, wash; the preparation and organ bath were washed with normal solution. The experimental solution was aerated with $100 \% \mathrm{O}_{2}$ and maintained at $37^{\circ} \mathrm{C}$.

A

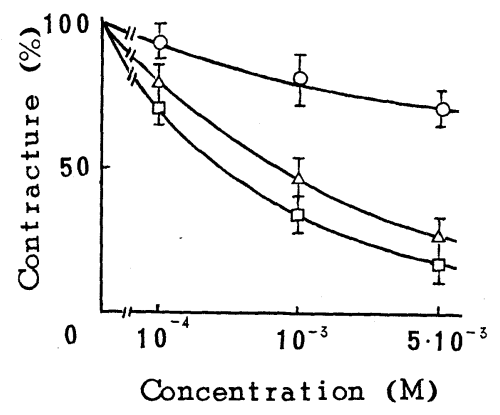

B

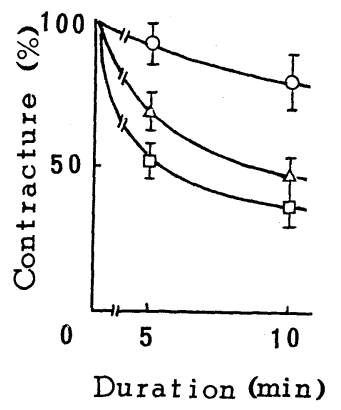

Fig. 2. Inhibitory effects of RR on K-contracture. A; Dose-inhibition curve of RR. $B$; Relationship between duration of RR pretreatment and inhibition of K-contracture. The preparation was pretreated with $10^{-3} \mathrm{M}$ RR for specified periods in Na-Tris sol. and immersed in K-Tris sol. containing the same concentration of RR. The ordinate of each figure shows inhibition by RR (Control tension of K-contracture was taken as $100 \%$ ). Each point represents the average for 6-9 experiments and vertical bars indicate SE $( \pm)$. O; phasic component of K-contracture, $\triangle$ and $\square$; tonic components at 10 and 15 min after initiation of $\mathrm{K}$-contracture, respectively. 
tonic component was more marked than that of phasic one.

The effects of $\mathrm{RR}$ and $\mathrm{La}^{3+}$ on K-contracture were compared. As shown in Fig. 3, $10^{-3} \mathrm{M} \mathrm{La}^{3+}$ suppressed the phasic component more markedly than the tonic component of $\mathrm{K}$-contracture. In the presence of $10^{-3} \mathrm{MRR}$ and $\mathrm{La}^{3+}$, both the phasic and tonic components of K-contracture were largely suppressed. These facts might indicate that specifically $\mathrm{RR}$ and $\mathrm{La}^{3+}$, respectively, affect the tonic and phasic components of K-contracture.
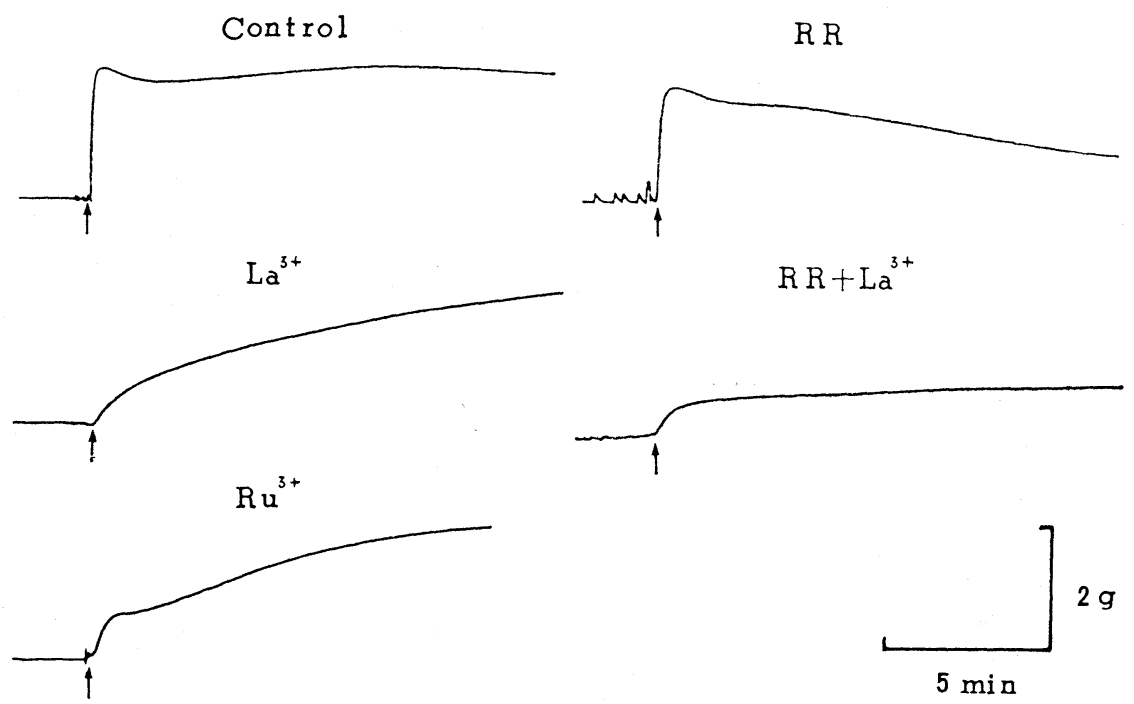

Fig. 3. Effects of various agents on K-contracture. The K-contracture shown in upperleft side hand of figure, transcribed from Fig. 1, served as the control. Records except "Control" show the effects of $\mathrm{RR}, \mathrm{La}^{3+}, \mathrm{RR}+\mathrm{La}^{3+}$ and ruthenium trichloride $\left(\mathrm{Ru}^{3+}\right)$. At each observation, the preparation was pretreated with the agent for $10 \mathrm{~min}$ in Na-Tris sol. and after transferred to K-Tris sol. containing the same concentration of its agent (at the time indicated by the arrow). The concentration of each agent was $10^{-3} \mathrm{M}$, respectively.

In order to investigate whether these inhibitory effects of RR were due to its characteristic chemical structure (a polynuclear ionic complex between oxygenbridged 3- and trivalent ruthenium atoms and ammonia) or to its polyvalent cationic sites, the effect of ruthenium trichloride $\left(\mathrm{Ru}^{3+}\right)$ on $\mathrm{K}$-contracture was examined. As shown in the lower left-hand corner of Fig. $3,10^{-3} \mathrm{M} \mathrm{Ru}^{3+}$ more markedly suppressed the phasic component than did $\mathrm{La}^{3+}\left(10^{-3} \mathrm{M}\right)$. This effect of $\mathrm{Ru}^{3+}$ obviously differs from that of $\mathrm{RR}$.

\section{Effects of $\mathrm{RR}$ and $\mathrm{La}^{3+}$ on cellular ${ }^{45} \mathrm{Ca}$ uptake}

Cellular ${ }^{45} \mathrm{Ca}$ uptake during $\mathrm{K}$-contracture in the presence of $10^{-3} \mathrm{M} \mathrm{RR}$, $10^{-3} \mathrm{M} \mathrm{La}^{3+}$ and in the coexistence of $10^{-3} \mathrm{M} \mathrm{RR}$ and $10^{-3} \mathrm{M} \mathrm{La}^{3+}$ was measured 
by the La method (UEMura, 1973).

The time relation of ${ }^{45} \mathrm{Ca}$ uptake, illustrated by the upper curve in Fig. 4, served as control for the other tests. This curve consisted of two components, an early rapid phase up to about $5 \mathrm{~min}$ and then a subsequent slow phase. Following the early phase, the amount of ${ }^{45} \mathrm{Ca}$ uptake further increased, coming saturated with about $0.12 \mathrm{mEq} / \mathrm{kg}$ wet wt about $20 \mathrm{~min}$ after the initiation of $\mathrm{K}$-contracture.

In the presence of $10^{-3} \mathrm{M} R \mathrm{R}$, the early rapid phase was unaffected but the subsequent slow phase was strongly suppressed, reaching a suppressed plateau about $20 \mathrm{~min}$ after the initiation of the K-contracture. In contrast, in the presence of $10^{-3} \mathrm{M} \mathrm{La}^{3+}$, the ${ }^{45} \mathrm{Ca}$ uptake in the early phase was completely inhibited but this inhibition was followed by a gradual increase of ${ }^{45} \mathrm{Ca}$ uptake about $1 \mathrm{~min}$ after the initiation of the K-contracture.

During coexistence of $10^{-3} \mathrm{M} \mathrm{RR}$ and $\mathrm{La}^{3+},{ }^{45} \mathrm{Ca}$ uptake in the early phase was completely blocked. After about $10 \mathrm{~min}$ exposure to K-Tris sol. containing RR $\left(10^{-3} \mathrm{M}\right)$ and $\mathrm{La}^{3+}\left(10^{-3} \mathrm{M}\right)$, there was a slight increase in ${ }^{45} \mathrm{Ca}$ uptake.

\section{Effects of $\mathrm{RR}$ and $\mathrm{La}^{3+}$ on superficial ${ }^{45} \mathrm{Ca}$ binding}

The amount of $\mathrm{Ca}^{2+}$ binding in the control solution, determined according to the procedure outlined in Methods AND Materials, is about $23 \pm 0.7 \mathrm{SE}$ nmoles/ $100 \mathrm{mg}$ wet wt (Table 1). In order to ascertain whether almost all of the bound

Table 1. ${ }^{45} \mathrm{Ca}$ binding to surface membrane of muscle cell. The preparations were incubated in a control solution (Na-Tris sol. containing $2 \mu \mathrm{Ci}{ }^{45} \mathrm{Ca} / \mathrm{ml}$ ) for $5 \mathrm{~min}$ under the conditions listed. After blotting, preparations were rinsed in $\mathrm{Ca}^{2+}$-free $\mathrm{Na}$-Tris sol. for $4 \mathrm{~min}$ and blotted again. The tissue was assayed for radioactivity according to the procedure described in the text. Each value represents the mean \pm SE for 6 12 experiments.

\begin{tabular}{|c|c|}
\hline Experiments & $\begin{array}{l}\text { Calculated amount of } \mathrm{Ca}^{2+} \\
\text { bound to surface membrane } \\
\text { (nmol/100 mg wet wt) }\end{array}$ \\
\hline Incubated in control solution at $20^{\circ} \mathrm{C}$ & $23.0 \pm 0.7 \quad(12)$ \\
\hline \multicolumn{2}{|l|}{ Prior treatments for $15 \mathrm{~min}$} \\
\hline with $10^{-3}$ M RR & $16.5 \pm 1.1$ \\
\hline with $10^{-3} \mathrm{M} \mathrm{La}^{3+}$ & $6.0 \pm 0.5$ \\
\hline \multicolumn{2}{|l|}{ After incubation in control solution, } \\
\hline $\begin{array}{l}\mathrm{Ca}^{2+} \text { binding was measured with the La } \\
\text { method (UEMURA, 1973) }\end{array}$ & $2.3 \pm 0.5$ \\
\hline Incubated in control solution at $37^{\circ} \mathrm{C}$ & $22.5 \pm 1.0 \quad(6)$ \\
\hline
\end{tabular}

$\mathrm{Ca}^{2+}$ measured was on the outer surface of the membrane or whether any amount was in intracellular space, the La method (UEMURA, 1973) was applied. Since $\mathrm{La}^{3+}$ has a much higher affinity for $\mathrm{Ca}^{2+}$ binding sites than $\mathrm{Ca}^{2+}$ itself, almost all the extracellular bound $\mathrm{Ca}^{2+}$ was displaced from tissue by $\mathrm{La}^{3+}$ while the intracellular $\mathrm{Ca}^{2+}$ remained locked inside the cells. With the use of this method, it was found that the amount of ${ }^{45} \mathrm{Ca}$ entering the cells during tissue exposure to a control solu- 
tion was $2.3 \pm 0.5 \mathrm{SE}$ nmoles $/ 100 \mathrm{mg}$ wet wt. This indicates that the large amounts of $\mathrm{Ca}^{2+}$ measured in the control solution of this study must be bound on the outer surface membrane. There was a difference between these two figures determined in each control experiment, the value was $56.6 \pm 4.1 \mathrm{SE}$ nmoles/100 mg wet wt in the report of IsHIYAMA et al. (1975), whereas it was $23 \pm 0.7 \mathrm{SE}$ nmoles/100 mg wet wt in the present study. Similar but not exactly identical experimental procedures were used in both experiments. One explanation for the discrepancy is that different durations were used in rinsing the tissue in $\mathrm{Ca}^{2+}$-free $\mathrm{Na}$-Tris sol. In the work of Ishiyama et al., the duration of rinsing was $10 \mathrm{sec}$, whereas it was $4 \mathrm{~min}$ in the present study. In general, it is evident from the ${ }^{45} \mathrm{Ca}$ efflux experiment that much more ${ }^{45} \mathrm{Ca}$ was effluxed from the tissue previously loaded with ${ }^{45} \mathrm{Ca}$ by prolongation of the rinsing. Because a more exact calculation in the analysis of $\mathrm{Ca}^{2+}$ binding is possible when a much more $\mathrm{Ca}^{2+}$ is bound, all $\mathrm{Ca}^{2+}$ binding experiments, other than those shown in Table 1, were done according to the method of Ishiyama et al.

The difference between control values at $20^{\circ} \mathrm{C}$ and $37^{\circ} \mathrm{C}$ was not statistically significant. Prior treatment with RR $\left(10^{-3} \mathrm{M}\right)$ decreased the amount of $\mathrm{Ca}^{2+}$ bound to the surface membrane from $23.0 \pm 0.7$ to $16.5 \pm 1.1 \mathrm{SE}$ nmoles/100 mg wet wt. Similarly, pretreatment with $\mathrm{La}^{3+}\left(10^{-3} \mathrm{M}\right)$ decreased bound $\mathrm{Ca}^{2+}$ to $6.0 \pm 0.5 \mathrm{SE}$ nmoles/100 mg wet wt.

Determination of high and low affinity sites of $\mathrm{Ca}^{2+}$ binding to the surface membrane

A Scatchard plot of the $\mathrm{Ca}^{2+}$ binding to the surface membrane revealed the existence of at least two classes of $\mathrm{Ca}^{2+}$ binding sites, of high and low affinity, respectively (ISHIYAMA et al., 1975).

In the present experiment, as shown in Table 2, 13.2, the ratio of bound $\mathrm{Ca}^{2+}$

Table 2. Determination of high and low affinity sites of $\mathrm{Ca}^{2+}$ binding to surface membrane of muscle cell. The preparation was incubated in Na-Tris sol. and then washed in $\mathrm{Ca}^{2+}$-free $\mathrm{Na}$-Tris sol. for $5 \mathrm{~min}$. Following this, the preparation was further incubated in $5 \mathrm{ml}$ of either $1.36 \cdot 10^{-5}$ or $1.36 \cdot 10^{-3} \mathrm{M} \mathrm{Ca}^{2+}$ containing Na-Tris sol. with $2 \mu \mathrm{Ci}{ }^{45} \mathrm{Ca} / \mathrm{ml}$ for $5 \mathrm{~min}$, at $20^{\circ} \mathrm{C}$, blotted, rinsed in $\mathrm{Ca}^{2+}$-free $\mathrm{Na}$-Tris sol. for $10 \mathrm{sec}$, and then blotted again. Two binding sites with different affinities were defined by the ratio of amounts of bound $\mathrm{Ca}^{2+}$ (nmoles/100 mg wet wt) to the concentration of added $\mathrm{Ca}^{2+}(\mathrm{M})$. Then the ratios obtained were multiplied by $10^{-4}$. Each value represents the mean $\pm \mathrm{SE}$ for 12 experiments.

\begin{tabular}{lcc}
\hline & $\begin{array}{c}\text { High affinity } \\
\text { binding site }\end{array}$ & $\begin{array}{c}\text { Low affinity } \\
\text { binding site }\end{array}$ \\
\hline $\begin{array}{l}\text { Added } \mathrm{Ca}^{2+} \text { (M) (a) } \\
\text { Bound } \mathrm{Ca}^{2+} \\
(\mathrm{nmol} / 100 \mathrm{mg} \text { wet wt) (b) }\end{array}$ & $1.36 \times 10^{-5}$ & $1.36 \times 10^{-3}$ \\
Ratio (b/a) & $1.79 \pm 0.12(12)$ & $80.7 \pm 4.4(12)$ \\
\hline
\end{tabular}

to added $\mathrm{Ca}^{2+}\left(1.36 \cdot 10^{-5} \mathrm{M}\right)$, was used to define high affinity sites. In contrast, 5.9 , the ratio determined in a high concentration of added $\mathrm{Ca}^{2+}\left(1.36 \cdot 10^{-3} \mathrm{M}\right)$, was 
used to define low affinity sites. The high and low affinity site values thus determined were nearly equal to those reported by IsHIYAMA et al. (1975).

As shown in Table $3,10^{-3} \mathrm{M}$ RR produced only a $15.1 \%$ decrease in $\mathrm{Ca}^{2+}$ binding to high affinity sites. On the other hand, it decreased $\mathrm{Ca}^{2+}$ binding to low affinity sites by $25.5 \%$. The effect of $\mathrm{La}^{3+}$ was contrasted with that of RR. One $\mathrm{mM} \mathrm{La}{ }^{3+}$ produced a $61.2 \%$ decrease in $\mathrm{Ca}^{2+}$ binding to high affinity sites, while it produced a $50.9 \%$ decrease in binding to low affinity sites.

The depressant effects of $\mathrm{RR}$ and $\mathrm{La}^{3+}$ on $\mathrm{Ca}^{2+}$ binding to both sites in isotonic

Table 3. Effects of RR and $\mathrm{La}^{3+}$ on high and low affinity sites of $\mathrm{Ca}^{2+}$ binding. The preparation was incubated in Na-Tris sol. either containing $10^{-3} \mathrm{M} R \mathbf{R}$ or $\mathrm{La}^{3+}$ for 15 min. Subsequent procedures are the same as described in the legend of Table 2. Each value represents the average for 6-9 experiments.

\begin{tabular}{cccccc}
\hline & \multicolumn{2}{c}{ High affinity site } & & \multicolumn{2}{c}{ Low affinity site } \\
Experiments & Ratio & $\begin{array}{c}\text { Inhibition } \\
(\%)\end{array}$ & & Ratio & $\begin{array}{c}\text { Inhibition } \\
(\%)\end{array}$ \\
\hline In Na-Tris sol. & 13.2 & & & 5.9 & \\
$\quad$ Control & 11.2 & 15.1 & & 4.4 & 25.5 \\
RR $\left(10^{-3} \mathrm{M}\right)$ & 5.1 & 61.2 & & 2.9 & 50.9 \\
$\mathrm{La}^{3+}\left(10^{-3} \mathrm{M}\right)$ & & & & \\
In K-Tris sol. & 12.7 & & & 5.8 & \\
$\quad$ Control & 10.9 & 14.5 & & 4.3 & 25.7 \\
$\mathrm{RR}^{\left(10^{-3} \mathrm{M}\right)}$ & 4.4 & 65.4 & & 3.1 & 46.2 \\
$\mathrm{La}^{3+}\left(10^{-3} \mathrm{M}\right)$ & & & & & \\
\hline
\end{tabular}

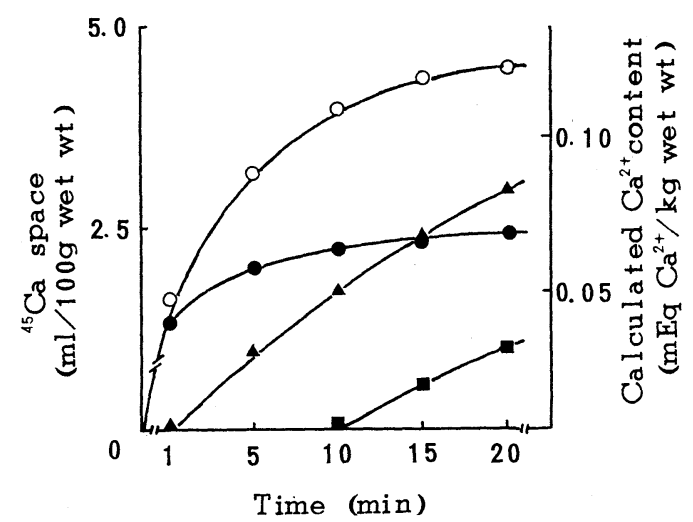

Fig. 4. Effects of $\mathrm{RR}, \mathrm{La}^{3+}$ and $\mathrm{RR}+\mathrm{La}^{3+}$ on cellular ${ }^{45} \mathrm{Ca}$ uptake during $\mathrm{K}$-contracture. Cellular ${ }^{45} \mathrm{Ca}$ uptake was measured by the La method. Details of the experimental procedure are described in the text. $O$; control, $\bullet$; in the presence of $10^{-3} \mathrm{M} R R$, $\Delta$; in the presence of $10^{-3} \mathrm{M} \mathrm{La}^{3+}, \boldsymbol{\square}$; in the coexistence of $10^{-3} \mathrm{M} \mathrm{RR}$ and $\mathrm{La}^{3+}$. The left ordinate represents ${ }^{45} \mathrm{Ca}$ space and right ordinate $\mathrm{Ca}^{2+}$ contents which were calculated from specific activities of radioisotope calcium and ${ }^{45} \mathrm{Ca}$ space. Each point represents the average for $6-9$ experiments. 
$\mathrm{KCl}$ solution were similar to those in normal solution.

\section{Electron micrograph of muscle cell stained with $R R$}

Ruthenium red has often been used as a histochemical staining dye because it selectively reacts with mucopolysaccharide to produce a stable RR-complex.

An electron micrograph (Fig. 5) of muscle cell exposed to $10^{-3} \mathrm{M} R \mathrm{R}$ in glutaraldehyde as well as in $\mathrm{OsO}_{4}$ shows that $\mathrm{RR}$ apparently did not penetrate into the muscle cell and only reacted with the outer surface of the muscle membrane and the surface vesicles.

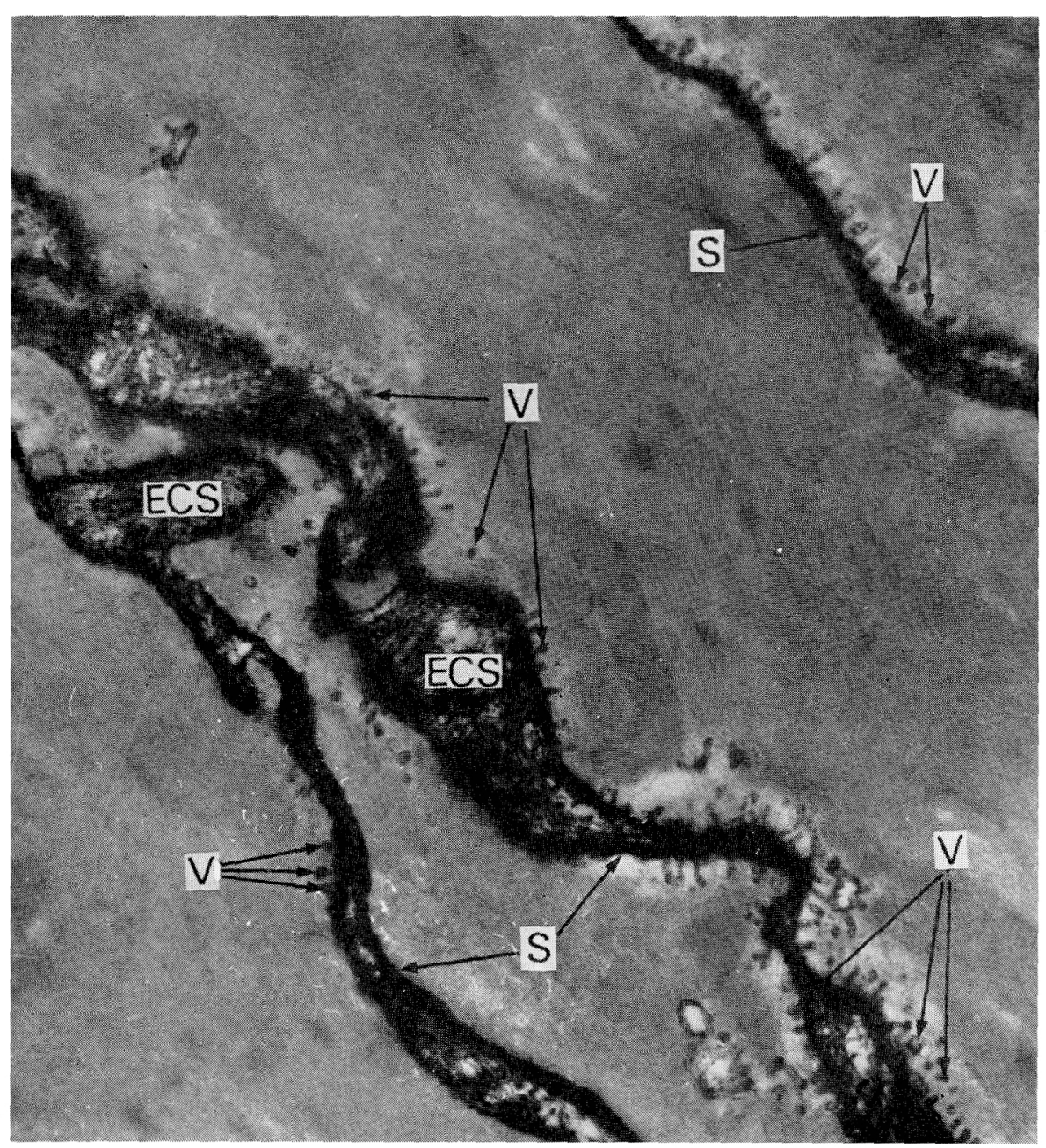

Fig. 5. Electron micrograph of muscle cell from guinea pig taenia coli stained with RR. Note the accumulation of RR exclusively on surface and vesicles of the cell membrane (arrows). Surface (S), vesicle (V) and extracellular space (ECS) are indicated, $\quad \times 30,000$. 


\section{DISCUSSION}

It is generally accepted that both the phasic and tonic components of $\mathrm{K}$-contracture of the taenia coli largely depend upon $\mathrm{Ca}^{2+}$ influx (MAYER et al., 1972; UEMURA, 1973).

In the present study, RR inhibited K-contracture of guinea pig taenia coli and its effect on the tonic component was found to be more marked than that on the phasic component (Figs. 1 and 2). This finding shows that in the case of the taenia coli the inhibitory effect of this agent on K-contracture is more specific to the tonic component than the phasic component.

Ruthenium red is reported to be a selective inhibitor of active $\mathrm{Ca}^{2+}$ uptake by microsomes from guinea pig taenia caecum (ToMIYAMA et al., 1975), by mitochondria from rat liver (MOORE, 1971) and by mitochondria from blowfly flight muscle (CARAFOLI and SACKTOR, 1972) and of the $\mathrm{Ca}^{2+}$-ATPase of erythrocyte membrane (WATSON et al., 1971). GILLIS (1972) showed that RR inhibited the relaxation of red muscle fiber which has few sarcoplasmic reticula, and interpreted this function in terms of inhibition of $\mathrm{Ca}^{2+}$ uptake by mitochondria. In addition, though this agent has been known as an extracellular marker in the field of light and electron microscope studies, Howell (1974) showed that when skeletal muscle was exposed to RR overnight a complete pattern of intracellular staining appeared.

Thus, if RR penetrates into the muscle cell of the taenia coli and acts as an inhibitor of $\mathrm{Ca}^{2+}$ uptake of some intracellular organella, i.e., sarcoplasmic reticulum or mitochondria, it might be expected that the tonic component of K-contracture would be facilitated by treatment with this agent. However, as shown in the photograph (Fig. 5) and in Fig. 1, RR neither penetrated into the muscle cells nor potentiated the tonic component of K-contracture. Therefore, in our experiment, it was concluded that RR did not act on intracellular membraneous organella but only on the outer surface of the muscle cell membrane.

It has been reported that $\mathrm{Ca}^{2+}$ binding to the negatively charged sites of surface membrane may be the first step for the influx of $\mathrm{Ca}^{2+}$ in barnacle skeletal muscle (HAgIWARA and TAKAHASHI, 1967), taenia coli smooth muscle (Brading and Widdicombe, 1977) and skeletal sarcoplasmic reticulum (CHEVAllier and Butow, 1971). IsHIYAma et al. (1975) also reported that a number of possible $\mathrm{Ca}^{2+}$ binding sites on the surface membrane of guinea pig taenia coli muscle might be sialic acid residues generated from mucopolysaccharide. Calcium is bound to a variety of cell membrane by coulombic interaction with negatively charged surface groups from sialic acid. In addition, RR is considered a polyanionic stain specific for sialic acid (MOORE, 1971; LUFT, 1971).

It has been reported that, in addition to the inhibitory effect of RR on the active $\mathrm{Ca}^{2+}$ uptake, $\mathrm{RR}$ also inhibits $\mathrm{Ca}^{2+}$ binding to mitochondrial membrane(VASINGTON et al., 1972), cardiac sarcolemma (SCARPA and WilliamsON, 1974), skeletal muscle sarcolemma (MADEIRA and ANTUNES-MADEIRA, 1974) and the membrane of skeletal sarcoplasmic reticulum (VALE and CARVALHO, 1973). In the present 
experiments, a clear inhibitory effect of $\mathrm{RR}$ on $\mathrm{Ca}^{2+}$ binding to the surface membrane was also observed. As shown in Fig. 4, in the presence of RR, cellular ${ }^{45} \mathrm{Ca}$ uptake in the early phase of $\mathrm{K}$-contracture was unaffected but that in its subsequent late phase was largely suppressed reaching a plateau level about $20 \mathrm{~min}$ after the initiation of $\mathrm{K}$-contracture. It is interesting to note that the time relation of cellular ${ }^{45} \mathrm{Ca}$ uptake in the presence of RR coincides with that of tension development in high $\mathrm{K}$ solution containing $\mathrm{RR}$ (Fig. 2A).

From the data presented, it appears that the effect of $\mathrm{RR}$ on the $\mathrm{Ca}^{2+}$ binding to the surface membrane is closely related to the inhibition of cellular $\mathrm{Ca}^{2+}$ uptake in the late phase of $\mathrm{K}$-contracture.

Recently, IsHIYAMA et al. (1975) reported the existence of two types of $\mathrm{Ca}^{2+}$ binding sites on the surface membrane of the taenia coli smooth muscle cell, one of high affinity and the other of low affinity. It was suggested that, the low affinity sites of $\mathrm{Ca}^{2+}$ binding might be sialic acid residues, thus being the first step in $\mathrm{Ca}^{2+}$ influx during K-contracture.

In our experiments, RR more markedly decreased the amount of $\mathrm{Ca}^{2+}$ bound to the low affinity sites that those of high affinity (Table 3).

Therefore, a possible explanation is that $\mathrm{RR}$ competes with $\mathrm{Ca}^{2+}$ binding sites of low affinity, causing a release of bound $\mathrm{Ca}^{2+}$ and a concurrent inhibition of $\mathrm{Ca}^{2+}$ influx. As a result of this decrease in $\mathrm{Ca}^{2+}$ influx, the tonic component of $\mathrm{K}$-contracture is suppressed.

In contrast, $\mathrm{La}^{3+}$ prevented the phasic component of $\mathrm{K}$-contracture, leaving the tonic component unaffected (Fig. 3) and largely decreased cellular $\mathrm{Ca}^{2+}$ uptake in the early phase of K-contracture (Fig. 4). Furthermore, it more markedly decreased the amount of $\mathrm{Ca}^{2+}$ bound to high affinity than low affinity sites (Table 3). In addition, it has been reported that $\mathrm{La}^{3+}$ can displace extracellularly bound $\mathrm{Ca}^{2+}$ and blocks the transmembrane $\mathrm{Ca}^{2+}$ movements of the taenia coli (MAYER et al., 1972; AdACHI, 1972; UEMURA, 1973).

Therefore, we would like to speculate that $\mathrm{La}^{3+}$ displaces $\mathrm{Ca}^{2+}$ from high affinity sites and blocks the influx of $\mathrm{Ca}^{2+}$ which might be related to the generation of the $\mathrm{Ca}^{2+}$ spike. Thus the phasic component of $\mathrm{K}$-contracture is suppressed.

The effects of $\mathrm{RR}$ and $\mathrm{La}^{3+}$ on $\mathrm{K}$-contracture, cellular $\mathrm{Ca}^{2+}$ uptake and superficial $\mathrm{Ca}^{2+}$ binding are summarized in Table 4 and a conceptional model consistent with this summary is illustrated in Fig. 6, i.e., $\mathrm{Ca}^{2+}$ influx appears to involve the binding of $\mathrm{Ca}^{2+}$ to negatively charged sites of the outer side of the membrane, followed by the transfer of $\mathrm{Ca}^{2+}$ from outer sites to inner sites in the membrane phase with the ultimate release of $\mathrm{Ca}^{2+}$ into myoplasm. Calcium binding sites may be composed of two classes with different affinity constants. Each site can be blocked selectively by differential inhibitors, i.e., $\mathrm{RR}$ and $\mathrm{La}^{3+}$. The low affinity $\mathrm{Ca}^{2+}$ binding sites, which are sensitive to $\mathrm{RR}$, are preferentially used for producing tonic component of $\mathrm{K}$-contracture, the high affinity sites which are accessible to $\mathrm{La}^{3+}$ for the phasic component. 
Table 4. Summary of RR and $\mathrm{La}^{3+}$ effects on contractility, on $\mathrm{Ca}^{2+}$ uptake and on

$\mathrm{Ca}^{2+}$ binding. Figures of $*, * *$ and $* * *$ are transcribed from Fig. 2, Fig. 4 and

Table 3, respectively.

\begin{tabular}{ccc}
\hline & Agents & \multicolumn{2}{c}{ Inhibition by } \\
\cline { 3 - 3 } Experiments & $\mathrm{RR}(\%)$ & $\mathrm{La}^{3+}(\%)$ \\
\hline K-contracture* & 10 & 80 \\
Phasic comp. & 65 & 5 \\
Tonic comp. & & 100 \\
$\mathrm{Ca}^{2+}$ uptake** & 12 & 24 \\
Rapid phase & 41 & \\
Slow phase & & 65.4 \\
$\mathrm{Ca}^{2+}$ binding site*** & 14.5 & 46.2 \\
High affinity & 25.7 & \\
Low affinity & &
\end{tabular}

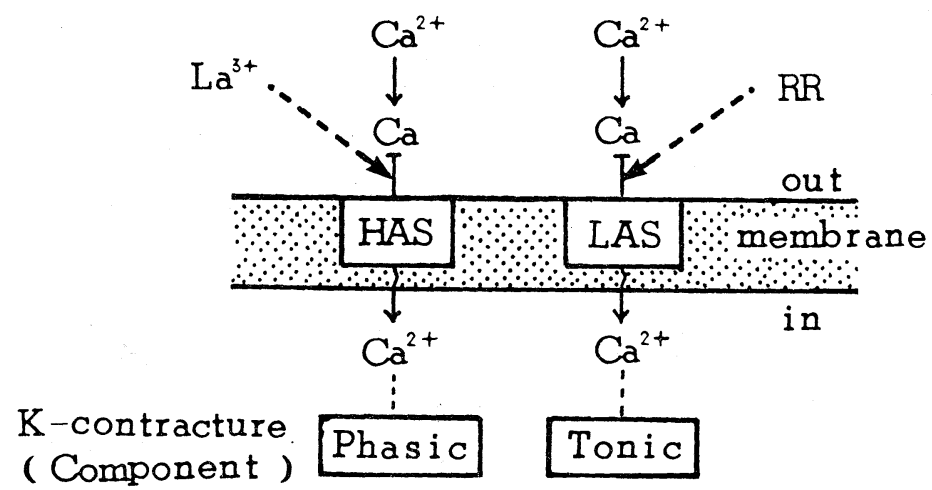

Fig. 6. Schematic illustration of possible $\mathrm{Ca}^{2+}$ movement across cell membrane of guinea pig taenia coli. Binding of $\mathrm{Ca}^{2+}$ to the outer surface of the cell membrane is the first step in $\mathrm{Ca}^{2+}$ influx. $\mathrm{Ca}^{2+}$ binding sites are composed of two classes with different affinity constants, i.e., high and low affinity sites. Each site can be blocked selectively by differential inhibitors, i.e., ruthenium red (RR) and lanthanum $\left(\mathrm{La}^{3+}\right) . \mathrm{Ca}^{2+}$ bound to the low affinity sites, which are sensitive to $\mathrm{RR}$, is preferentially available for producing the tonic component of K-contracture. Conversely, the high affinity sites are more accessible to $\mathrm{La}^{3+}$. HAS and LAS indicate high and low affinity sites, respectively. .$- \rightarrow$; inhibition by $\mathrm{RR}$ or $\mathrm{La}^{3+}$.

According to the work of Ishiyama et al., the removal of sialic acid residues by neuraminidase produced not only inhibition of both phasic and tonic components of K-contracture but abolition of $\mathrm{Ca}^{2+}$ binding sites of low affinity. From these facts, they proposed that $\mathrm{Ca}^{2+}$ binding to sialic acid residues plays a crucial role in the regulation of transmembrane $\mathrm{Ca}^{2+}$ flux in taenia coli. On the other hand, we used RR for perturbation of sialic acid residues. Ruthenium red decreased the amount of $\mathrm{Ca}^{2+}$ bound on the binding sites of low affinity and more markedly inhibited the tonic component than the phasic component. Our results 
indicate that $\mathrm{Ca}^{2+}$ binding sites of low affinity are generated by sialic acid residues and are consistent with the concept that sites for control of $\mathrm{Ca}^{2+}$ flux to form the tonic component are sialic acid residues. While both we and Ishiyama et al. studied two perturbations in investigating the crucial role of sialic acid residues in $\mathrm{Ca}^{2+}$ flux; both experiments brought about different results concerning the inhibition of K-contracture; i.e., neuraminidase suppressed both the phasic and tonic components, whereas RR selectively inhibited the tonic component. The reason for this discrepancy is unclear at present due to the fact that the chemical nature of the high affinity sites has not yet been elucidated. Mela (1968) suggested that in mitochondrial membrane, phospholipid residues have a high affinity for $\mathrm{La}^{3+}$. Phospholipase $\mathrm{C}$ suppressed both the tonic and phasic components (IshiYAma et al., 1975). In the present study $\mathrm{La}^{3+}$ decreased the $\mathrm{Ca}^{2+}$ binding to high affinity sites and inhibited the phasic component more markedly than the tonic one. Therefore, the inhibition of both components by neuraminidase might partly be due to the associated decomposition of membraneous phospholipid.

The authors gratefully make acknowledgements to Prof. E. Miyazaki, Department of Physiology, and Prof. H. Hayasaka, Department of Surgery, Sapporo Medical College, for valuable discussion and Dr. H. Iwano, Department of Surgery, Sapporo Medical College for the electron microscope study. This work was supported by a research grant from the Ministry of Education, Science and Culture of Japan.

\section{REFERENCES}

ADACHI, T. (1972) Effects of lanthanum and manganese on noradrenaline contraction, potassium contracture and $\mathrm{Ca}$ movements in vascular smooth muscle. Sapporo Med. J., 41: 123-139 (in Japanese).

Bosmann, H. B., Myers, M. W., Dehond, D., Ball, R., and Case, K. R. (1972) Mitochondrial autonomy. Sialic acid residues on the surface of isolated rat cerebral cortex and liver mitochondria. J. Cell Biol., 55: 147-160.

Brading, A. F. and Widdicombe, J. H. (1977) The use of lanthanum to estimate the numbers of extracellular cation-exchanging sites in the guinea-pig's taenia coli, and its effects on transmembrane monovalent ion movements. J. Physiol., 266: 255-273.

Carafoli, E. and SackTor, B. (1972) The effects of ruthenium red on reactions of blowfly flight muscle mitochondria with calcium. Biochem. Biophys. Res. Commun., 49: 1498-1503.

Chevallier, J. and Butow, R. A. (1971) Calcium binding to the sarcoplasmic reticulum of rabbit skeletal muscle. Biochemistry, 10: 2733-2737.

Gillis, J. M. (1972) Le rôle du calcium dans le controle intracellulaire de la contraction musculaire. Thesis, Université catholique de Louvain, Louvain, Belgium, cited by MADEIRA, V. M. C. and ANTunes-MAdeIRA, M. C. (1974) Interaction of ruthenium red with isolated sarcolemma. J. Membr. Biol., 17: 48 p.

Hagiwara, S. and TAKahashi, K. (1967) Surface density of calcium ions and calcium spikes in the barnacle muscle fiber membrane. J. Gen. Physiol., 50: 583-601.

Howell, J. N. (1974) Intracellular binding of ruthenium red in frog skeletal muscle. J. Cell Biol., 62: 242-247.

IsHIYAMA, Y., YABU, H., and MIYAZAKI, E. (1975) Changes in contractility and calcium binding of guinea pig taenia coli by treatment with enzymes which hydrolyze sialic acid. Jap. J.

Vol. 28, No. 4, 1978 
Physiol., 25: 719-732.

KaWamura, M., YABU, H., and MiYazaki, E. (1977) Selective inhibition of isotonic K contracture of guinea pig taenia coli. Proc. Intern. Physiol. Sci., 13:13 p.

Larsén, C., Dallner, G., and ERnSter, L. (1972) Association of sialic acid with microsomal membrane structures in rat liver. Biochem. Biophys. Res. Commun., 49: 1300-1306.

LoNG, C. and Mouat, B. (1971) The binding of calcium ions by human erythrocytes. Biochem. J., 121: $15 \mathrm{p}$.

LuFT, J. H. (1971) Ruthenium red and violet. II. Fine structural localization in animal tissues. Anat. Res., 171: 369-416.

Madeira, V. M. C. and Antunes-Madeira, M. C. (1974) Interaction of ruthenium red with isolated sarcolemma. J. Membr. Biol., 17: 41-51.

MAYer, C. J., van Breemen, C., and Casteels, R. (1972) The action of lanthanum and D600 on the calcium exchange in the smooth muscle cells of the guinea-pig taenia coli. Pflügers Arch., 337: 333-350.

MeLA, L. (1968) Interactions of $\mathrm{La}^{3+}$ and local anesthetic drugs with mitochondrial $\mathrm{Ca}^{2+}$ and $\mathrm{Mn}^{2+}$ uptake. Arch. Biochem. Biophys., 123: 286-293.

MOORE, C. L. (1971) Specific inhibition of mitochondrial $\mathrm{Ca}^{2+}$ transport by ruthenium red. Biochem. Biophys. Res. Commun., 42: 298-305.

Rossi, C. S., Vasington, F. D., and Carafoli, E. (1973) The effect of ruthenium red on the uptake and release of $\mathrm{Ca}^{++}$by mitochondria. Biochem. Biophys. Res. Commun., 50: 846852.

Sanborn, W. G. and Langer, G. A. (1970) Specific uncoupling of excitation and contraction in mammalian cardiac tissue by $\mathrm{La}^{+++}$. J. Gen. Physiol., 56: 191-217.

SCARPA, A. and Williamson, J. R. (1974) Calcium binding and calcium transport by subcellular fractions of heart. In: Calcium Binding Proteins, ed. by Drabikowski, W., StrZeleckaGotaszewska, H., and Carafoli, E. PWN-Polish Scientific Publishers, Warszawa, pp. 547-586.

ShLATZ, L. and MARINeTti, G. V. (1972) Calcium binding to the rat liver plasma membrane. Biochim. Biophys. Acta, 290: 70-83.

TomiYama, A., TAKAYANAGI, I., and TAKAGI, K. (1975) Relationships between $\mathrm{Ca}^{2+}$ uptake by a microsomal fraction of guinea-pig taenia coli caecum and its relaxation. Biochem. Pharmacol., 24: 9-12.

Uemura, K. (1973) ${ }^{45} \mathrm{Ca}$ movements in guinea pig taenia coli. Sapporo Med. J., 42: 270-283 (in Japanese).

Vale, M. G. P. and Carvalho, A. P. (1973) Effects of ruthenium red on $\mathrm{Ca}^{2+}$ uptake and ATPase of sarcoplasmic reticulum of rabbit skeletal muscle. Biochim. Biophys. Acta, 325: $29-37$.

Vasington, F. D., Gazzotti, P., Tiozzo, R., and Carafoli, E. (1972) The effect of ruthenium red on $\mathrm{Ca}^{2+}$ transport and respiration in rat liver mitochondria. Biochim. Biophys. Acta, 256: 43-45.

Watson, E. L., VincenzI, F. F., and Davis, P. W. (1971) $\mathrm{Ca}^{2+}$-activated membrane ATPase: Selective inhibition by ruthenium red. Biochim. Biophys. Acta, 249: 606-610. 